\title{
A ILEGIMIDADE DEMOCRÁTICA DAS DECISÕES DO SUPREMO TRIBUNAL FEDERAL, SOB O ENFOQUE DA TEORIA DE JEREMY WALDRON
}

\author{
Luís Carlos Balbino Gambogi* \\ Marcelo Matos de Oliveira**
}

\section{RESUMO}

Esse texto tem como temática a relação entre constitucionalismo e democracia e o debate das teorias política e jurídicas no âmbito da jurisdição constitucional brasileira, quando se apresenta como ambiente de solução de controvérsias sobre questões morais que surgem numa sociedade democrática. Questiona-se se caberia ao Supremo Tribunal Federal exercer o judicial review sobre a antecipação do cumprimento da pena sem a comprovação definitiva da culpa (Repercussão Geral no Agravo em Recurso Extraordinário 964246/SP). O marco teórico adotado é a dignidade da legislação de Jeremy Waldron. Utilizar-se-á, com predominância, o raciocínio dedutivo, por meio da pesquisa bibliográfica e jurisprudencial.

Palavras-chave: Jurisdição constitucional; Supremo Tribunal Federal; Legitimidade democrática; Dignidade da legislação; Jeremy Waldron.

\section{THE DEMOCRATIC ISSUES OF SUPREME COURT SENTENCES, ACCORDING TO JEREMY WALDRON TEORY}

\begin{abstract}
This paper has as its theme the relationship between constitutionalism and democracy, and also debate of political and legal theories within scope Brazilian constitutional jurisdiction when it presents itself as an environment for resolving controversies on moral issues that arise in a democratic society. It is questioned whether it would be up to Supreme Federal Court to carry out judicial review on anticipation of serving sentence without definitive proof of guilt (General Repercussion in Appeal in Extraordinary Appeal 964246/SP). The theoretical framework adopted is dignity legislation of Jeremy Waldron. Deductive reasoning will be used predominantly through bibliographic and jurisprudential research.
\end{abstract}

Key words: Judicial control of constitutionality; Supreme Court; Democratic letimacy; Dignity of legislation; Jeremy Waldron.

\footnotetext{
* Professor Dr. PPGD FUMEC. Desembargador do Tribunal de Justiça do Estado de Minas Gerais (TJMG). Doutor em Filosofia pela UFMG. gambogi@fumec.br

** Bacharel em Direito pela FUMEC, Pós-graduado em Direito Público pela Faculdade de Direito Izabela Hendrix, Mestre em Direito Público pela Universidade FUMEC, Assessor Judiciário TJMG e Professor de Direito Penal. marcelooabmg@hotmail.com
} 


\section{INTRODUÇÃO}

Se a democracia significou uma garantia de autogoverno com a ampla participação de todos na tomada de decisões públicas, o constitucionalismo simbolizou a união do povo em torno de um projeto de Estado fundado na supremacia constitucional e na garantia de igualdade de direitos a todos, por mais heterogêneos que sejam seus projetos de vida nas sociedades democráticas. Os juízes, a seu turno, foram concebidos como os guardiães das normas constitucionais para garantir efetividade desses direitos sensíveis frente às investidas das maiorias legislativas circunstanciais.

A relação entre constitucionalismo e a democracia, nas sociedades modernas, envolve uma tensão sensível e tem exigido intenso debate das teorias jurídicas e da política. E essa tensão se agrava nas sociedades em que a jurisdição constitucional assume papel de instância de representação argumentativa qualificada e passa a equacionar dissensos morais relevantes, ditando-lhes a última palavra.

Esse estudo se propõe a discutir a ideia da centralidade da legislação e o papel exercido pelo princípio majoritário como regra de tomada de decisão acerca de questões morais. Traz-se a teoria da oposição ao judicial review (JR) de Jeremy Waldron, considerando-se os pressupostos do caso essencial, para reconhecer que o parlamento é o locus adequado para a promoção da interação de debate de pontos de vista distintos da sociedade a fim de resolver questões de direitos. Se a premissa é a inevitabilidade do desacordo, por serem da própria essência do direito, deve-se definir um processo decisório equânime e respeitável para solucioná-lo sem que se rompa a legitimidade democrática da decisão.

Notadamente o Supremo Tribunal Federal, com suas atribuições redefinidas na Constituição da República de 1988 (Brasil, 2019), acabou por assumir papel de verdadeira centralidade em meio às demais funções do Estado na formação da identidade política do povo.

Ao fim da análise, verifica-se uma incongruência existente entre o precedente do Supremo Tribunal Federal (Repercussão Geral no Agravo em Recurso Extraordinário no 964.246/SP) (BRASIL, 2016) e a vontade do legislador, tanto constitucional, quanto ordinário, erigida ao longo das últimas décadas e explicitada no sentido de que ninguém pode ser preso a não ser em flagrante delito ou por ordem escrita e fundamentada da autoridade 
judiciária competente, em decorrência de sentença condenatória transitada em julgado ou em virtude de prisão provisória - temporária ou preventiva.

A temática é relevante porque decisões como aquela vêm vinculando as instâncias ordinárias desde os respectivos julgamentos, trazendo insegurança jurídica em cada alteração diametral de entendimento pelo Plenário. Outrossim, os julgados têm revelado profunda incerteza sobre um desfecho acerca da questão entre os julgadores, porque sempre com votações apertadas, com diferença de um único voto. Além disso, tais modificações diametrais ocorreram em menos de uma década.

O trabalho foi desenvolvido, além da introdução, em outros três capítulos, a saber, o que trata da teoria da dignidade da legislação de Jeremy Waldron, com a apresentação das quatro pressuposições do denominado caso essencial, o que trata da necessidade de resgate da dignidade da legislação diante do julgado paradigma do Supremo Tribunal Federal acerca da antecipação do cumprimento da pena desde a condenação em segunda instância, para em seguida se firmar o fechamento do trabalho com a conclusão.

O marco teórico usado é a teoria adotada por Jeremy Waldron, o qual busca resgatar a dignidade da atividade do Legislativo para solução dos casos denominados essenciais.

O raciocínio adotado, com predominância, é o dedutivo, o método descritivo e o tipo bibliográfico e jurisprudencial.

\section{A DIGNIDADE DA LEGISLAÇÃO EM JEREMY WALDRON}

Antes de delimitar o alvo da sua crítica, Waldron traz considerações sobre o judicial review (JR) e as posições da batalha entre quem o apoia e quem o refuta, conforme se verá a seguir.

Se a participação de todos nas tomadas de decisões públicas é o direito dos direitos, a preocupação de Waldron é resgatar a dignidade da legislação. E ele vai questionar por que essa atividade fruto da regra majoritária é tão malvista.

\subsection{Considerações iniciais e o judicial review}


Em defesa da sua teoria, registre-se que Waldron não se olvidou em momento algum em emprestar de forma realista a reputação da atividade dos parlamentos. Tanto é que inferiu que:

Parece que tal fórum é considerado indigno das questões mais graves e sérias dos direitos humanos que uma sociedade moderna enfrenta. $\mathrm{O}$ pensamento parece ser que os tribunais, com suas perucas e cerimônias, seus volumes encadernados em couro e seu relativo isolamento ante a política partidária, sejam um local mais adequado para solucionar questões desse caráter. (WALDRON, 2003, p. 5).

A preocupação de Waldron com o resgate da dignidade da legislação não faz emergir tão somente o questionamento "quem se decide?, mas também o "o que se decide?", e "como se decide?". Tanto é que o filósofo inicia uma de suas obras com a pergunta: “os juízes deveriam ter autoridade para revogar leis quando estiverem convencidos de que elas violam direitos individuais?" (WALDRON, 2010, p. 93).

Há quem valorize o JR por entender que agora as questões dos direitos estão sendo enfrentadas de forma direta, firme e seriamente (DWORKIN, 2002). Nessa linha, chega-se a reconhecer que o JR leva a más decisões - como quando ocorreu com a derrubada de leis trabalhistas no caso Lochner $v N Y^{1}$, do ano de 1905, e que também padeça de algum tipo de déficit democrático. Mas se conclui, de um lado, que o processo democrático dificilmente é perfeito e, de outro, que um mau resultado ocasional do JR é tolerável, diante do comprometimento da sociedade com direitos individuais ante maiorias preconceituosas (WALDRON, 2010, p. 93-94).

A seu turno, Waldron reconhece o valor de muitas decisões que o JR proferiu, mas ao mesmo tempo defende que a revisão sobre a legislação é inapropriada como modelo de tomada de decisão final em uma sociedade livre e democrática. Cita-se a expressão dificuldade contramajoritária ${ }^{2}$, que significa a possibilidade de os juízes, apesar de não eleitos, poderem invalidar deliberações do legislador escolhido pelo voto.

\footnotetext{
${ }^{1}$ A Suprema Corte dos Estados Unidos acolheu por cinco a quatro o pedido de Joseph Lochner, proprietário de uma padaria em Utica/NY, quando impugnou leis benéficas aos trabalhadores - limitação de jornada dos padeiros e proteção da saúde. A Corte afastou a alegação de que a jornada com mais de dez horas tivesse relação com danos à saúde dos trabalhadores ou perda da qualidade dos pães. Acrescentou que a classe de padeiro não era especial e possuía capacidade de barganhar direitos diretamente com seus empregadores. Por fim, disse que a lei impugnada violava a $14^{\mathrm{a}}$ Emenda, que limitava o poder de polícia dos Estados. O entendimento vencedor não levou em conta que tal trabalho extenuante causava reumatismo, câimbras e fraqueza nas pernas. Para os dissidentes, a decisão deveria levar em consideração o poder inerente dos Estados para zelar pela vida, saúde e bem-estar dos seus cidadãos (WEDY; FREITAS, 2015).

2 Expressão adotada pelo autor romeno Alexander Bickel, na obra "The least dangerous branch" (BICKEL, 1986).
} 
Os regimes democráticos se caracterizam por uma ampla abertura à participação política, ou seja, maior número de pessoas com igual direito de votar e ser votado em eleições livres e periódicas, acatando-se a decisão da maioria. Com essa ideia de participação, Waldron tenta desestabilizar o argumento convencional favorável às cortes constitucionais, denunciando seu caráter antidemocrático (WALDRON, 2010).

Waldron diz que, em países nos quais não se permite que a legislação seja invalidada pelo JR, o próprio povo pode decidir pelo procedimento ordinário legislativo - como questões do aborto, cotas escolares, casamento homossexual e ações afirmativas. A título de exemplo, Waldron afirma que debates sobre tais questões ocorreram em vários países na esfera pública - Grã-Bretanha, Nova Zelândia, Canadá, Austrália, todos de forma comprometida e responsável nas respectivas casas legislativas. Diante disso, tornou-se vazia, segundo o autor, a afirmação de que as maiorias populares nunca apoiam ou apoiariam os direitos das minorias (WALDRON, 2010, p. 95).

Ao tratar de sua teoria, Waldron cita Ronald Dworkin, rotulando-o como defensor do JR, e diz que ele coloca - quanto a questões controvertidas, profundas de moralidade política e há séculos debatidas por filósofos - que o povo e seus representantes devem simplesmente aceitar os pronunciamentos de uma maioria de juízes (WALDRON, 2010, p. 95). O apoio à prática da revisão judicial da lei vinha dos liberais e a oposição dos conservadores, que iam contra os direitos que os tribunais liberais sustentavam e faziam reconhecer. Não se desconhece que também houve crescimento da oposição liberal ao JR, como no caso em que a Corte de Rehnquist, de forma conservadora, derrubou conquistas significativas da política legislativa liberal ${ }^{3}$. O aniversário de 200 anos de Marbury v. Madison, segundo Waldron:

[...] suscitou numerosas discussões sobre suas origens e legitimidade original, ao passo que o aniversário de 50 anos de Brown v. Board of Edication forneceu um lembrete oportuno dos serviços prestados pelos tribunais norteamericanos em meados do séc. XX quando encabeçou o ataque a leis de segregação e outras leis racistas.(WALDRON, 2010, p. 96).

Em síntese, o que Waldron enfatiza é a preocupação acerca de um entendimento geral, não contaminado por preocupações políticas, culturais e históricas de cada sociedade, sobre escolhas morais razoáveis em questão, em caso de discordâncias entre cidadãos.

\footnotetext{
${ }^{3}$ United States v. Morrison, 2000, em que derrubou parte da Lei da Violência contra a mulher; United States v. lopez, 1995, em que se decidiu que o Congresso não tem autoridade para legislar uma proibição à posse de armas num determinado perímetro de uma escola (ESTADOS UNIDOS, 2000).
} 
A análise do JR, em Waldron, vai se limitar à revisão de legislação que seja promulgada por um parlamento eleito de um Estado organizado politicamente, afastando expressamente atos do Executivo. O filósofo também vai concentrar sua crítica nos sistemas de controle forte de constitucionalidade da legislação e em seu caráter a posteriori, por um tribunal constitucional erigido especificamente para avaliar a forma abstrata de projetos de lei nos estágios finais de sua promulgação.

Feitas essas considerações, cumpre trazer a lume as quatro pressuposições do caso essencial.

\subsection{As quatro pressuposições do caso essencial}

Como mencionado anteriormente, a objeção de Waldron ao JR não é incondicional. $\mathrm{O}$ autor busca distinguir os casos essenciais e os não essenciais, focando sua oposição em face do controle relativo àqueles, ou seja, que abarquem as situações em que determinadas pressuposições se mostrem claramente evidentes numa sociedade. Sem a satisfação de tais pressuposições, a oposição não resistirá.

As pressuposições são: instituições democráticas em condições razoáveis de funcionamento; instituições judiciais tradicionais; comprometimento com direitos; e a discordância sobre direitos.

Para o filósofo, deve-se imaginar uma sociedade que possua:

1) Instituições democráticas em condições de funcionamento razoavelmente boas, incluindo um legislativo representativo, eleito pelo sufrágio universal; 2) um conjunto de instituições judiciais, também em boas condições de funcionamento, erigidas sobre uma base não representativa para conhecer das ações individuais, resolver controvérsias e defender o Estado de Direito; 3) um comprometimento da parte da maioria dos membros da sociedade e da maioria de suas autoridades com a ideia de direitos individuais e de minorias e 4) discordância persistente, substancial e de boa fé quanto a direitos (isto é, quanto ao que realmente significa o comprometimento com direitos e quais são as suas implicações) entre os membros da sociedade que estão comprometidos com a ideia de direitos. (WALDRON, 2010, p. 106).

Cumpridas as pressuposições, uma sociedade deve decidir sobre suas discordâncias relativas a direitos e questões morais pela via legislativa. E Waldron acrescenta que:

Se essas pressuposições se sustentarem, a posição a favor de consignar tais discordâncias ao judiciário para a resolução final é fraca e não convincente, não havendo necessidade de as decisões legislativas sobre direito serem reavaliadas pelos tribunais. (WALDRON, 2010, p. 106). 
$\mathrm{Na}$ sequência, trata-se, isoladamente, de cada uma das quatro pressuposições levantadas na teoria de Waldron.

\subsubsection{Instituições democráticas}

Parte-se do princípio de que a sociedade tem um sistema político amplamente democrático, com voto universal adulto e um legislativo representativo e íntegro, com eleições periódicas e em uma base imparcial e regular. Também se considera que o parlamento é um órgão deliberativo numeroso, habituado a apreciar e decidir sobre questões difíceis, e os procedimentos são dignos de confiança, com diversos mecanismos de proteção, como o bicameralismo, comissões parlamentares e níveis múltiplos de debate - em que seus membros se veem ora como legítimos representantes de seus eleitores como elemento chave de sua participação, ora pensando mais em termos de representação de toda a sociedade de um modo mais amplo (WALDRON, 2010, p. 106-107).

Waldron não quis dizer que as instituições são perfeitas, mas que estão funcionando bem e sustentadas numa cultura democrática que valoriza a deliberação responsável e igualdade política. Quando diz que as instituições estão em boas condições de funcionamento, não faz presumir que toda a legislação produzida seja justa quanto ao seu conteúdo. Ao contrário, ele pressupõe que parte da produção legislativa é justa e outra não, as pessoas discordam sobre qual é qual e que algumas normas podem ser submetidas ao JR e, em relação a outras, ninguém fará tal proposição (WALDRON, 2010, p. 108).

$\mathrm{O}$ argumento do filósofo começa a emergir: uma vez estabelecida essa primeira premissa, que razão existiria para se querer erigir um processo não eletivo para revisar - e algumas vezes anular - o trabalho feito pelo parlamento?

\subsubsection{Instituições judiciais}

O bom estado de funcionamento dos tribunais depende de sua independência política e de um suporte estável e adequado para conhecer de ações, deliberar sobre controvérsias sob o corolário do devido processo legal e defender o Estado de direito. Waldron pressupõe, ainda, que tais instituições - que são não representativas e seus membros não se veem 
permeados pelo ethos de eleições - estão aptas e autorizadas a desempenhar o JR caso provocadas (WALDRON, 2010, p. 109).

Sobre essa pressuposição, está claro que as instituições poderiam desempenhar o JR, mas a questão para Waldron é saber se deveriam e, se positivo, se suas deliberações seriam finais e vinculariam as demais funções representativas do Estado.

Waldron não descarta certo tipo de controle de constitucionalidade, pois nem sempre é fácil para os legisladores verem quais questões de direitos estão insertas nas propostas legislativas apresentadas para análise e não menos difícil é vislumbrar quais questões de direito poderiam surgir a partir da sua aplicação posterior.

Em suma, Waldron parte do pressuposto de que os tribunais i) não agem por impulso ou por referência abstrata; ii) lidam com questões de natureza contenciosa e iii) remetem às próprias decisões anteriores e as aperfeiçoam em aspectos relevantes para o caso em análise. E parte do princípio de que existe uma hierarquia de tribunais, com órgãos compostos por diversos membros, com as instâncias inferiores se submetendo às decisões daqueles em casos iguais (WALDRON, 2010, p. 109).

Por fim, assevera que os seus membros, caso tenham o poder de exercer o JR, devem estar comprometidos com os direitos como qualquer outra pessoa imersa na sociedade democrática. Assim, como qualquer outro membro da sociedade, também discordarão sobre direitos e o procedimento decisório usado, como se regra, será o da maioria simples.

\subsubsection{Comprometimento com direitos}

Sobre a terceira pressuposição, tem-se como base que existe entre os membros de uma sociedade robusto comprometimento com a ideia de direitos individuais e das minorias.

Esses cidadãos, apesar de acreditarem no governo da maioria como um princípio geral básico, são cientes de que as minorias gozam de direitos, que não seriam garantidos pela inferioridade de seu número ou peso político.

Waldron parte do princípio de que "o comprometimento com direitos não são palavras vazias e que os membros da sociedade levam direitos a sério" e acrescenta que "o respeito geral pelos direitos individuais e de minorias é uma parte séria de um consenso amplo na sociedade" (WALDRON, 2010, p. 111). 
Com relação aos casos não essenciais, em que o compromisso com os direitos é frágil, Waldron diz que, por vezes, nesse cenário:

[...] precisamos do judicial review para ajudar a fortalecer nosso comprometimento com direitos, para ensinar aos participantes de uma nova democracia a valorizar direitos ou para dar às minorias garantias que não estão disponíveis em um sistema puramente governado pela maioria. (WALDRON, 2010, p. 112).

Superados os três primeiros pressupostos, traz-se a lume a seguir o último, que é a existência, numa sociedade democrática e complexa, de discordâncias sobre direitos.

\subsubsection{Discordância sobre direitos}

A quarta e última pressuposição, segundo Waldron, trata das discordâncias razoáveis e de boa-fé. Ele não descarta sustentações insinceras, desinformadas, dotadas de perversidade ou rivalidade por poder e status, mas defende que a maioria das discordâncias se dá daquela forma. São escolhas que as sociedades modernas plurais devem enfrentar, opções que são razoavelmente bem entendidas no contexto de debates morais e políticos, que são o cerne da discordância moral e política entre os seus membros (WALDRON, 2010, p. 113). Apesar de ser a discordância inevitável nas sociedades, reconhece-se que as posições contrárias sobre direitos devem ser levadas a sério justamente por serem seus membros agentes morais dotados de responsabilidade e comprometidos com direitos de uma forma geral. E nem seria crível esperar que os pontos de vista e posições das pessoas quanto a questões complexas de direitos convergiriam num consenso simples - como nos casos do aborto, direitos de acusados de crimes, ações afirmativas contra discriminação de minorias, tolerância religiosa, regulamentação de discursos e gastos em campanhas eleitorais.

Waldron diz que tais discordâncias não são apenas questões de interpretação em um sentido estritamente legalista ou características comportamentais dos membros das sociedades em que elas surgem, e acrescenta que:

[...] duas pessoas que discordam se as restrições a discurso de ódio racista são aceitáveis podem, ambas, aceitar a questão e podem também aceitar que o caso sobre o qual discordam é central, em vez de ser marginal, em relação àquele direito. Isso demonstra, talvez, que têm concepções diferentes do direito, mas não é razão para duvidar da sinceridade de sua adesão a ele. (WALDRON, 2010, p. 114).

Adimplidas aquelas pressuposições, Waldron pergunta: "o que faremos com a situação que elas definem?” (WALDRON, 2010, p. 116). Como visto, nos casos essenciais, os membros da sociedade estão comprometidos com direitos, mas naquele meio surgem 
discordâncias que devem ser resolvidas, não reacendidas. Ele diz que são necessárias soluções nem tanto para a eliminação da questão, mas para se ter uma base de ação comum quando for necessário agir. Em outras palavras, a busca pelo consenso não faz desaparecer o fato de existirem discordâncias, mas se deve produzir uma base comum de ação quando elas surgirem.

Suponha-se que o parlamento esteja plenamente ciente das questões de direitos que certo projeto de lei suscite e que, após deliberar sobre ele, resolva, por meio de amplo debate e votação, conciliá-las de uma maneira específica, ou seja, posicionar-se de um dos lados da discordância. A pergunta é saber se essa decisão do Legislativo poderia ou não ser reavaliada ou até mesmo anulada pelo Judiciário. Como responder? Ao citar pensamento de Hobbes sobre a questão, Waldron diz que “[...] mesmo que os membros da sociedade que estamos imaginando discordem sobre direitos, eles precisam compartilhar uma teoria de legitimidade para o procedimento decisório que deve conciliar suas discordâncias" (WALDRON, 2010, p. 118), e não reacender controvérsias.

Sobre um procedimento decisório, Waldron repete que nenhum deles será perfeito e ainda critica a assertiva de que as maiores chances de erro estão no Legislativo, pois seja num procedimento legislativo, seja num JR, pode-se chegar a uma decisão errada (WALDRON, 2010, p. 119).

Traçadas as quatro pressuposições de Waldron e identificado o seu alvo - controle de constitucionalidade forte, a posteriori, da produção legislativa, para fazer a exposição geral da crítica, buscar-se-á resgatar a dignidade da legislação no caso essencial paradigma desse trabalho, a saber, a Repercussão Geral no Agravo em Recurso Extraordinário no 964.246/SP (BRASIL, 2016).

\section{A NECESSIDADE DE RESGATE DA DIGNIDADE DA LEGISLAÇÃO}

Antes de examinar o caso concreto sugerido para fechamento da abordagem feita da teoria de Waldron na sua busca pela centralidade da legislação e pelo resgate de sua dignidade nos casos essenciais, registra-se que não se propõe aqui tecer qualquer crítica ou comentário acerca do caminho teórico e critérios hermenêuticos trilhados pelo Supremo Tribunal Federal para subsidiar a tomada de decisão no caso paradigma da Repercussão Geral no Agravo em Recurso Extraordinário no 964.246/São Paulo, julgado em 10 de novembro de 2016 pelo 
Órgão Pleno (BRASIL, 2016). Da mesma forma, não é objeto de discussão identificar se com a decisão houve retrocesso no que respeita ao direito de liberdade da pessoa.

A seguir, verificar-se-á, no caso mencionado, se é possível legitimar a sobreposição de decisões ocorrida entre o Parlamento e o Judiciário e se ali, naquele julgado, houve ou não ruptura dos limites institucionais de cada função.

\subsection{Análise do caso da repercussão geral no Agravo em Recurso Extraordinário no 964.246/São Paulo}

Pelo julgamento do Agravo em Recurso Extraordinário nº 964.246/SP (BRASIL, 2016), por maioria apertada, o Supremo Tribunal Federal promoveu substantiva modificação do entendimento até então em vigor naquele órgão e, por vinculação, nos demais que compõem o Judiciário no Brasil.

A guinada antagônica firmou ser cabível a expedição do mandado de prisão em desfavor de alguém com decreto condenatório mantido ou proferido em segunda instância, mesmo sem se alcançar em definitivo sua responsabilidade criminal.

Tal entendimento foi de encontro à vontade do legislador infraconstitucional, que vinha demonstrando a preocupação em garantir a efetivação dos direitos fundamentais frente à ânsia estatal de punir antes mesmo da formação da culpa do agente, tudo isso como medida de defesa social para satisfazer o sentimento de justiça da sociedade, de preservação do sistema e de sua suposta confiabilidade.

Os limites institucionais da prisão preventiva, sob o enfoque dos dispositivos do art. $5^{\circ}$, incisos LIV $^{4}$ e LVII ${ }^{5}$, ambos da Constituição da República de 1988 (BRASIL, 1988), bem como da (in)eficácia do há pouco elaborado dispositivo do art. 283 do Código de Processo Penal $^{6}$ (BRASIL, 1941), são pontos de discussão e análise.

Não podem ser olvidados os princípios insculpidos na Declaração Universal dos Direitos Humanos de 1948 (ORGANIZAÇÃO DAS NAÇÕES UNIDAS, 2009), a qual

\footnotetext{
4 "Ninguém será privado da liberdade ou de seus bens sem o devido processo legal" (BRASIL, 1988).

5 "Ninguém será considerado culpado até o trânsito em julgado de sentença penal condenatória" (BRASIL, 1988).

6 "Ninguém poderá ser preso senão em flagrante delito ou por ordem escrita e fundamentada da autoridade judiciária competente, em decorrência de sentença condenatória transitada em julgado ou, no curso da investigação ou do processo, em virtude de prisão temporária ou prisão preventiva." (Redação dada pela Lei n ${ }^{\circ}$ 12.403, de 2011) (BRASIL, 1941).
} 
reforçou, após o colapso da Segunda Guerra Mundial, os valores universais dos direitos humanos, em especial, os artigos $8^{\circ}$ e 11 , que tratam do estado de inocência, do devido processo legal e da prestação jurisdicional.

A partir desta nova abordagem do Supremo Tribunal Federal sobre a execução provisória quase automática após a segunda instância, a qual alterou diametralmente posição firmada desde o Habeas Corpus (HC) no 84.078/MG, julgado em 5 de maio de 2009 pelo Órgão Pleno (BRASIL, 2009), dúvidas surgiram no que diz respeito à atuação do Judiciário quando se defronta com desacordos morais dispostos na sociedade.

Resta responder, então, a questão: Podem fórmulas genéricas judiciais servir de substrato à prisão cautelar mesmo em sem a presença dos respectivos requisitos previstos em lei?

A questão é de extrema relevância, pois aquele posicionamento do Supremo Tribunal Federal, por ter repercussão geral, desde novembro de 2016, vinha vinculando os magistrados no sentido de se expedir mandados de prisão de condenados em tribunais de segundo grau mesmo sem o esgotamento de recursos, em clara contraposição ao texto normativo outrora produzido pelo Congresso Nacional.

Sobre essa alteração, vale trazer a lume parte das ementas dos julgados acima citados:

EMENTA: HABEAS CORPUS. INCONSTITUCIONALIDADE DA CHAMADA "EXECUÇÃO ANTECIPADA DA PENA". ART. $5^{\circ}$, LVII, DA CONSTITUIÇÃO DO BRASIL. DIGNIDADE DA PESSOA HUMANA. ART. $1^{\circ}$, III, DA CONSTITUIÇÃO DO BRASIL. [...]. A Constituição do Brasil de 1988 definiu, em seu art. $5^{\circ}$, inciso LVII, que "ninguém será considerado culpado até o trânsito em julgado de sentença penal condenatória". 2. Daí que os preceitos veiculados pela Lei n. 7.210/84, além de adequados à ordem constitucional vigente, sobrepõem-se, temporal e materialmente, ao disposto no art. 637 do CPP. 3. A prisão antes do trânsito em julgado da condenação somente pode ser decretada a título cautelar. 4. A ampla defesa, não se a pode visualizar de modo restrito. Engloba todas as fases processuais, inclusive as recursais de natureza extraordinária. Por isso a execução da sentença após o julgamento do recurso de apelação significa, também, restrição do direito de defesa, caracterizando desequilíbrio entre a pretensão estatal de aplicar a pena e o direito, do acusado, de elidir essa pretensão. [...]. 6. A antecipação da execução penal, ademais de incompatível com o texto da Constituição, apenas poderia ser justificada em nome da conveniência dos magistrados --- não do processo penal. A prestigiar-se o princípio constitucional, dizem, os tribunais [leiase STJ e STF] serão inundados por recursos especiais e extraordinários e subseqüentes agravos e embargos, além do que "ninguém mais será preso". Eis o que poderia ser apontado como incitação à "jurisprudência defensiva", que, no extremo, reduz a amplitude ou mesmo amputa garantias constitucionais. A comodidade, a melhor operacionalidade de funcionamento do STF não pode ser lograda a esse preço. [...] É inadmissível a sua exclusão social, sem que sejam consideradas, em quaisquer circunstâncias, as singularidades de cada infração penal, o que somente se pode apurar plenamente quando transitada em julgado a 
condenação de cada qual Ordem concedida. (BRASIL, 2009).

CONSTITUCIONAL. RECURSO EXTRAORDINÁRIO. PRINCÍPIO CONSTITUCIONAL DA PRESUNÇÃO DE INOCÊNCIA (CF, ART. $5^{\circ}$, LVII). ACÓRDÃO PENAL CONDENATÓRIO. EXECUÇÃO PROVISÓRIA. POSSIBILIDADE. REPERCUSSÃO GERAL RECONHECIDA. JURISPRUDÊNCIA REAFIRMADA. 1. Em regime de repercussão geral, fica reafirmada a jurisprudência do Supremo Tribunal Federal no sentido de que a execução provisória de acórdão penal condenatório proferido em grau recursal, ainda que sujeito a recurso especial ou extraordinário, não compromete o princípio constitucional da presunção de inocência afirmado pelo artigo $5^{\circ}$, inciso LVII, da Constituição Federal. 2. Recurso extraordinário a que se nega provimento, com o reconhecimento da repercussão geral do tema e a reafirmação da jurisprudência sobre a matéria. (BRASIL, 2016).

Como já mencionado há pouco, o Parlamento, tanto ao promulgar a Constituição da República (BRASIL, 2019), quanto em recente modificação do Código de Processo Penal, em seu art. 283 , fez demonstrar a sua vontade no sentido de que:

\footnotetext{
Ninguém poderá ser preso senão em flagrante delito ou por ordem escrita e fundamentada da autoridade judiciária competente, em decorrência de sentença condenatória transitada em julgado ou, no curso da investigação ou do processo, em virtude de prisão temporária ou prisão preventiva. (BRASIL, 2018).
}

Em outras palavras, a legislação processual penal, atualizada pelo Parlamento no ano de 2011, com o advento da Lei $\mathrm{n}^{\circ} 12.403$ (BRASIL, 2011), reafirmou expressamente que uma pessoa só poderia ter privada a liberdade em flagrante delito, por decisão judicial pela prisão temporária ou preventiva ou sentença condenatória definitiva.

Digno de nota, o Projeto de Lei $n^{\circ} 4.208$ (BRASIL, 2001), de iniciativa do Executivo, apresentado em 12.3.2001, que se transformou na Lei $\mathrm{n}^{\mathrm{o}}$ 12.403 (BRASIL, 2011), tramitou por mais de década no Parlamento - Câmara dos Deputados e Senado Federal, foi objeto de apreciação em diversas comissões temáticas, incluindo-se a de Constituição e Justiça e de Cidadania, juntaram-se diversos pareceres de juristas a respeito para subsidiar e enriquecer o debate entre os membros do Congresso Nacional.

A seu turno, o Supremo Tribunal Federal, em patente contrariedade, decidiu que não seria necessário aguardar o trânsito em julgado da condenação para se determinar o início do cumprimento da pena do agente infrator.

Levando em consideração os argumentos trazidos nesse trabalho, pode-se entender que a Lei $\mathrm{n}^{\mathrm{o}} 12.403$ (BRASIL, 2011) foi produto do debate num ambiente - o Parlamento razoavelmente comprometido com direitos, eleito por cidadãos insertos em instituições democráticas que se encontram em bom funcionamento, quando estava a se decidir entre opções relativas à flexibilização ou não do estado de inocência e punitivismo. 
Independentemente da anuência substancial da decisão judicial relativa à permissão de se antecipar a execução da pena privativa de liberdade, do ponto de vista da democracia, observa-se um déficit de representatividade nessa atuação maximizadora do Supremo Tribunal Federal.

O que se vê, de fato, mesmo em um caso tido por essencial na teoria de Waldron, foi a alteração do direito produzido pelo Parlamento por meio de provocação, que significou, ao reacender nova discussão, verdadeira inovação no ordenamento e desarmonia com o princípio da separação das funções sem qualquer deferência ao Legislativo.

\section{CONCLUSÃo}

Pelas premissas teóricas apresentadas por Waldron, buscou-se demonstrar a razão pela qual o judicial review baseado em direitos é inapropriado para sociedades razoavelmente democráticas, cujo principal problema não é o fato de suas instituições legislativas serem disfuncionais, mas o fato de seus membros discordarem sobre direitos.

O Judiciário exerce a função de interpretar e aplicar a lei, mas cabe ao Legislativo, como o locus mais adequado e legítimo, realçar as questões morais em jogo quando as pessoas de uma sociedade discordam sobre direitos, pois é ali que elas participarão de forma democrática da tomada de decisões, e as aceitarão, ainda que delas discordem.

De igual forma, inoportuno e de caráter antidemocrático é emprestar a função representativa e majoritária ao Supremo Tribunal Federal, até porque o Legislativo, no caso em análise, não adotou posição inerte ou omissa quanto a suas atribuições institucionais. Veja-se que tanto na Constituição da República (BRASIL, 1988) quanto na legislação processual penal (BRASIL, 1941) está clara a vontade do Parlamento acerca dos direitos debatidos no julgamento.

A última palavra sobre os mais importantes desacordos políticos e morais entre membros de uma sociedade deve ser dada pelos representantes eleitos e reunidos em uma assembleia, que é o locus mais adequado para a função, ainda que com suas deficiências. Não é demais repensar que à medida que os membros de dada sociedade participam e ao mesmo tempo se sentem atores da tomada de decisões, ainda que dela discordem, mais facilmente as aceitarão. Isso gera harmonização social, consenso e é fator de coesão. A atividade política não se trata de mera politicagem. 
Por certo, o direito não é resultado único e exclusivo da atividade parlamentar, pois agentes e membros de outras funções do Estado, a seu modo e regulação, também editam normas e afetam de forma genérica e abstrata a vida das pessoas. Porém, a reunião dos representantes da sociedade, numa assembleia representativa, é o meio democrático de se decidir sobre questões morais e direitos.

A tentativa de redesenhar o papel do Supremo Tribunal Federal e o princípio da separação das funções, como verdadeira concentração de poder do Judiciário como última instância para a deliberação sobre questões morais numa sociedade plural e complexa, não fortalecerá a democracia, mas a enfraquecerá.

O debate parlamentar nem sempre tende a ofender minorias quando se encontra em razoáveis condições de funcionamento, pelo que suas deliberações - diante de suas credenciais democráticas, transparência e numerosidade de membros - devem ser prestigiadas e respeitadas sem necessidade de revisão, porque são as que democraticamente representam a vontade popular.

Pensar de forma diferente seria permitir que poucos, num exercício amplo de interpretação da Constituição para além da análise de validade da norma, imponham à sociedade seus próprios valores e sua régua moral, o que não há que se admitir numa sociedade democrática.

\section{REFERÊNCIAS}

BICKEL, Alexander M. The Least Dangerous Branch: the Supreme Court at the bar of politics. 2. ed. Yale University Press, 1986.

BRASIL. [Constituição (1988)]. Constituição da República Federativa do Brasil de 1988. Brasília, DF: Presidência da República, [2019]. Disponível em: http://www.planalto.gov.br/ccivil_03/Constituicao/Constituicao.htm. Acesso em: 15 abr. 2020.

BRASIL. Decreto-Lei no 3.689, de 3 de outubro de 1941. Código de Processo Penal. Brasília, DF: Presidência da República, [2018]. Disponível em: http://www.planalto.gov.br/ccivil_03/decreto-lei/Del3689.htm. Acesso em: 20 abr. 2020.

BRASIL. Lei $\mathbf{n}^{\circ}$ 12.403, de 4 de maio de 2011. Altera dispositivos do Decreto-Lei $\mathrm{n}^{\mathbf{0}} 3.689$, de 3 de outubro de 1941 - Código de Processo Penal, relativos à prisão processual, fiança, liberdade provisória, demais medidas cautelares, e dá outras providências. Brasília, DF: Presidência da República, [2011]. Disponível em: 
http://www.planalto.gov.br/CCIVIL_03/_Ato2011-2014/2011/Lei/L12403.htm. Acesso em: 15 abr. 2020.

BRASIL. Projeto de Lei $\mathbf{n}^{\mathbf{0}} \mathbf{4 . 2 0 8}$, de 12 de março de 2001. Altera dispositivos do DecretoLei no 3.689, de 3 de outubro de 1941 - Código de Processo Penal, relativos à prisão, medidas cautelares e liberdade, e dá outras providências. Brasília, DF: Câmara dos Deputados, 2001. Disponível em:

http://www.camara.gov.br/proposicoesWeb/fichadetramitacao?idProposicao=26558. Acesso em: 15 abr. 2020.

BRASIL. Supremo Tribunal Federal (Tribunal Pleno). Repercussão Geral no Recurso Extraordinário com Agravo 964246/SP. Constitucional. Recurso Extraordinário. Princípio constitucional da presunção de inocência (CF, art. $\left.5^{\circ}, \mathrm{LVII}\right)$. Acórdão penal condenatório. Execução provisória. Possibilidade. Repercussão geral reconhecida. Jurisprudência reafirmada. 1. Em regime de repercussão geral, fica reafirmada a jurisprudência do Supremo Tribunal Federal no sentido de que a execução provisória de acórdão penal condenatório proferido em grau recursal, ainda que sujeito a recurso especial ou extraordinário, não compromete o princípio constitucional da presunção de inocência afirmado pelo artigo $5^{\circ}$, inciso LVII, da Constituição Federal. 2. Recurso extraordinário a que se nega provimento, com o reconhecimento da repercussão geral do tema e a reafirmação da jurisprudência sobre a matéria. Recorrente: M. R. D. Recorrido: Ministério Público do Estado de São Paulo. Relator: Min. Teori Zavascki, 10 de novembro de 2016. Disponível em:

http://www.stf.jus.br/portal/jurisprudencia/listarJurisprudencia.asp?s1=\%28964246\%2ENUM E\%2E+OU+964246\%2EPRCR\%2E\%29\&base=baseRepercussao\&url=http://tinyurl.com/ju8 2opf. Acesso em: 20 abr. 2020.

BRASIL. Supremo Tribunal Federal (Tribunal Pleno). Habeas Corpus 84078/MG. Habeas Corpus. Inconstitucionalidade da chamada "execução antecipada da pena". Art. $5^{\circ}$, LVII, da Constituição do Brasil. Dignidade da pessoa humana. Art. $1^{\circ}$, III, da Constituição do Brasil [...]. Impetrante: Omar Coelho Vitor. Relator: Min. Eros Grau, 26 de fevereiro de 2010. Disponível em:

http://www.stf.jus.br/portal/jurisprudencia/listarJurisprudencia.asp?s1=\%2884078\%2ENUME $\% 2 \mathrm{E}+\mathrm{OU}+84078 \% 2 \mathrm{EACMS} \% 2 \mathrm{E} \% 29 \&$ base=baseAcordaos\&url=http://tinyurl.com $/ \mathrm{hmu} 88 \mathrm{w}$ m. Acesso em: 15 abr. 2020.

DWORKIN, Ronald. Uma questão de princípio. São Paulo: Martins Fontes, 2002.

ESTADOS UNIDOS. Suprema Corte. United States v. Morrison, n. 529. Washington, 15 de maio de 2000. Disponível em: https://supreme.justia.com/cases/federal/us/529/598/. Acesso em: 15 abr. 2020.

ORGANIZAÇÃO DAS NAÇÕES UNIDAS. Declaração Universal dos Direitos Humanos. Rio de Janeiro: UNIC, 2009. Disponível em: https://nacoesunidas.org/wpcontent/uploads/2018/10/DUDH.pdf. Acesso em: 15 abr. 2020.

WALDRON, Jeremy. A dignidade da legislação. São Paulo: Martins Fontes, 2003. 
WALDRON, Jeremy. A essência da oposição ao "judicial review". In: BIGONHA, Antônio Carlos Alpino; MOREIRA, Luiz (org.). Legitimidade da jurisdição constitucional. Rio de Janeiro: Lumen Juris, 2010. p. 93-157.

WALDRON, Jeremy. A dignidade da legislação. São Paulo: Martins Fontes, 2003.

WEDY, Gabriel; FREITAS, Juarez. Regulação razoável: Dissenso no caso Lochner v. New York deixou um legado nos EUA. Revista Consultor Jurídico, 3 jun. 2015. Disponível em: https://www.conjur.com.br/2015-jun-03/dissenso-lochner-new-york-deixou-legado-eua2. Acesso em: 15 abr. 2020. 